\title{
Risk assessment for antibiotic resistance in South East Asia
}

\author{
Fanny Chereau and colleagues assess the risk of the emergence and spread of antibiotic \\ resistance in South East Asia and suggest it is the highest of the World Health Organization regions
}

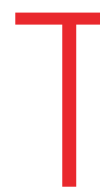

he indiscriminate use of antibiotics in human and veterinary medicine and food production and the release of antibiotics into the environment have led to the emergence of antibiotic resistant bacteria and genes. The effectiveness of antibiotics is compromised by the growing resistance, and controlling antibiotic resistance is a priority for the World Health Organization. ${ }^{1}$ Knowledge is lacking about the biological determinants of the emergence and spread of antibiotic resistance. Evaluating these determinants is important to identify effective interventions to contain antibiotic resistance.

Weak surveillance systems and a lack of data make it difficult to estimate the extent of antibiotic resistance in the WHO South East Asia region. We carried out a qualitative risk assessment to evaluate the relative effects of the main determinants of antibiotic resistance and to estimate the risk of the emergence and spread of antibiotic resistance among humans in the WHO South East Asia region.

\section{Methods \\ We used the risk assessment approach outlined in box 1 to characterise the level of risk-that is, the likelihood of the emer- gence and spread of antibiotic resistance among humans-in the WHO South East Asia region. The region includes 11 coun- tries: Bangladesh, Bhutan, Democratic People's Republic of Korea, India, Indone- sia, Maldives, Myanmar, Nepal, Sri Lanka, Thailand, and Timor-Leste.}

\section{Hazard assessment}

We first assessed the specific hazards by identifying the important antibiotic resist-

\section{KEY MESSAGES}

- South East Asia is at high risk of the emergence and spread of antibiotic resistance in humans

- The risk assessment framework can help countries identify interventions for maximum impact, although isolated interventions will be inadequate

- A comprehensive strategy using the One Health approach is needed to contain antibiotic resistance in South East Asia

\section{Box 1: Risk assessment approach and definitions}

- Risk: Likelihood of the occurrence of a health event

- Risk assessment: A systematic process to gather, assess, and document information to assign a level of risk. ${ }^{2}$ It provides the basis for taking action to manage the negative consequences of public health risks. The level of risk assigned to an event depends on a specific hazard, exposure to this hazard, and the context in which the event is occurring. Risk assessment includes three components:

- Hazard assessment: identification of the hazard(s) causing the event of interest

- Exposure assessment: evaluation of how, and how much, a person, or a population is exposed to the hazard(s)

- Context assessment: evaluation of the environment in which the event is taking place. Context factors include socioeconomic, ecological, or programmatic factors

- Risk characterisation: It combines the findings from the hazard, exposure, and context assessments to assign a level of risk of the occurrence of the event of interest ant bacteria and associated antibiotic resistant genes, such as those with high attributable mortality and high potential for transmission.

WHO has identified seven bacteria with high levels of antibiotic resistance (box 2). ${ }^{3}$ Of these, extended spectrum $\beta$-lactamase and carbapenemase producing Enterobacteriaceae and meticillin resistant Staphylococcus aureus (MRSA) are of greatest concern, as infections have high mortality. ${ }^{4}$ These pathogens are also commensal bacteria in humans and animals (healthy carriage) and in the environment (water and soil). In the South East Asia region healthy carriage of and infections by extended spectrum $\beta$-lactamase producers and MRSA are common. ${ }^{3567}$

\section{Exposure assessment}

We then described the processes that lead to the acquisition, selection, and spread of the resistant bacteria and genes in humans. The exposure assessment identified the reservoirs (human, animal, and environment) from which antibiotic resistance can emerge, the transmission routes both within and between reservoirs, and the bio- logical determinants of the emergence and transmission of antibiotic resistance. The transmission routes for human acquisition of the antibiotic resistant pathogens are shown in fig 1.

The widespread use of antibiotics in human and veterinary medicine for therapeutic or prophylactic purposes is the main driver of the acquisition and selection of antibiotic resistant bacteria. ${ }^{891011}$ The resulting release of active or unmetabolised antibiotics from human and animal waste, from aquaculture, and from pharmaceutical companies into the environment further increases the risk of selection of antibiotic resistance. ${ }^{1213}$

Transmission of resistant bacteria and genes to humans is caused by ingestion of contaminated food or water and by direct contact with contaminated animals, soil, or water. ${ }^{813141516}$ Spread within the human population depends on the capacity for sustained human-to-human transmission. This capacity is still poorly understood. ${ }^{17}$ In humans, spread of resistance can occur both in the community and in healthcare settings. ${ }^{1819}$ High levels of antibiotic use, high density of at-risk individuals, and poor hand hygiene in healthcare settings lead to

\section{Box 2: Bacteria with high levels of antibiotic resistance ${ }^{3}$}

- Gram negative bacteria-Neisseria gonorrhoeae with decreased susceptibility to third generation cephalosporins, and Escherichia coli, Klebsiella pneumoniae, Shigella spp, and non-typhoidal salmonella with resistance to third generation cephalosporins (including resistance conferred by extended spectrum $\beta$-lactamases) and fluoroquinolones or carbapenems

- Gram positive bacteria-meticillin resistant Staphylococcus aureus and penicillin resistant Streptococcus pneumoniae 


\section{SEAR's antibiotic challenge}

Risks of emergence and spread of antibiotic resistance in South East Asia

The WHO South East Asia Region (SEAR) has unique characteristics that contribute to the likelihood of increasing resistance to antibiotics developing in the region. In their 2017 model published in The BMJ, Chereau and colleagues use a risk assessment approach to characterise the likelihood of emergence and spread of antibiotic resistance in the region. They conclude that the overall risk for emergence and spread of antibiotic resistance among humans in South East Asia is high.

Access to water and soap in the household can be very limited. Combined with poor knowledge and education about hygiene, transmission of antibiotic resistant strains is a high risk

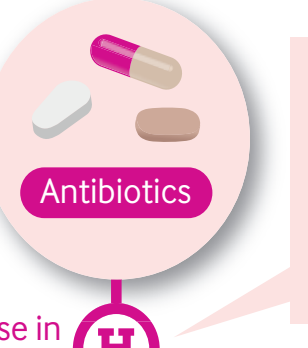

Stewardship is low across the region. Antibiotics are widely available without prescriptions or are inappropriately prescribed

humans

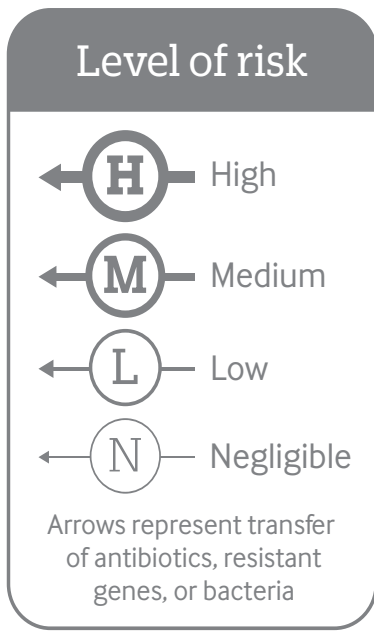

Poor implementation of infection prevention programmes, limited resources, and poor awareness among healthcare professionals lead to a high burden of endemic healthcare associated infections
While some countries have food safety policies, these are often poorly enforced. Meat consumption remains limited across the region but is increasing
Ingestion of contaminated meat
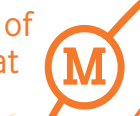

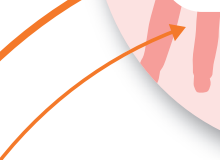

(C) Eneregere

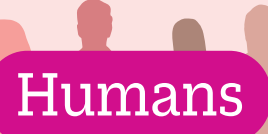

Hospital setting

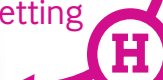

Antibiotic residues

from untreated

human waste

\section{Animals}

Antibiotic residues

from untreated livestock

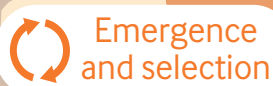

Use in animals

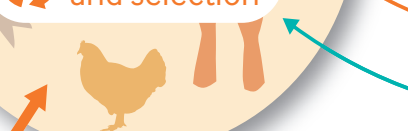
waste

Ingestion of contaminated food or water

Few countries have a legal framework for antibiotic stewardship in animals. Increasingly intensive livestock production is also a feature of the region, which involves an increase in use of antimicrobials
Antibiotic residues are released into the environment from human activities. Effluents from healthcare sites, inappropriate disposal of unused antibiotics, and pharmaceutical waste pose a particularly significant risk. The problems are compounded by poor wastewater management and inefficient treatment technology 
increased transmission of resistant strains from patients or healthcare workers to other patients by direct contact or through contaminated surfaces. ${ }^{112021}$ The use of antibiotics in the community is thought to be even greater than in healthcare settings and further increases human-to-human transmission of antibiotic resistance. ${ }^{11}$

MRSA and extended spectrum $\beta$-lactamase strains from healthcare settings or community outbreaks often differ from livestock associated strains. ${ }^{22}$ This could suggest a limited transmission capacity of strains from animal or environmental origin in humans. ${ }^{1723}$ These species barriers are not well understood, and this lack of knowledge impedes the risk assessment process, particularly about the acquisition of resistant bacterial strains from another reservoir.

\section{Context assessment}

We assessed the factors specific to the WHO South East Asia region that could affect the causes of the emergence and transmission of resistant strains. The factors were examined at the policy level (scope of policies and guidelines to contain antibiotic resistance in the region), system level (implementation of policies, healthcare system management, wastewater management, and agriculture and livestock management), and individual level (human behaviour and beliefs).

We gathered information from peer reviewed articles, press articles, published documents from WHO, the Food and Agriculture Organization, and Unicef and from unpublished WHO reports. Because of the lack of data available at the country level, the context assessment considered the region as a whole.

Several context factors in the region increase the risk of acquisition, selection, and spread of antibiotic resistance (table 1). Awareness of the drivers of antibiotic resistance, particularly inappropriate antibiotic use, is low among the public and health professionals in most countries of the region. ${ }^{42}$ Unregulated antibiotic distribution and poor implementation of antibiotic stewardship programmes in humans ${ }^{27}$ lead to overuse and misuse of antibiotics. Wastewater management is inadequate. About $75 \%$ of wastewater is not treated in the countries of the region and is directly released into the environment, thus contaminating natural drinking water sources where access to piped or improved water supplies is limited. ${ }^{37}$ Even when water is treated, the effectiveness of removal of contaminants is limited. ${ }^{33}$

The lack of antibiotic stewardship programmes results in the inappropriate use of antibiotics in livestock and aquaculture. Furthermore, poor infection control practices in farms lead to the selection and spread of resistant strains. ${ }^{31}$ Antibiotic use in livestock is expected to rise because of increased production in response to a growing demand for food from animal sources. ${ }^{32}$ International food safety and quality standards have reduced antibiotic use in animal products intended for export; however, the same is not true for livestock products for domestic consumption. Other regional challenges include the limited ability to detect and measure resistance in the human population. Our recent analysis of national programmes to tackle antimicrobial resistance ${ }^{43}$ showed limited capacity for microbiology and antibiotic susceptibility testing in most public hospitals in the region; only Thailand has data on the national trends for extended spectrum $\beta$-lactamase and carbapenemase producing Enterobacteriaceae. Early diagnosis and active surveillance are lacking thus delaying implementation of infection control measures. Also, efforts to identify animal and environmental reservoirs and to detect antibiotic resistance in the food chain and water systems are limited across the region. ${ }^{31}$

\section{Risk characterisation for the WHO South East Asia region}

To characterise the level of risk of the emergence and spread of antibiotic resistance among humans in the WHO South East Asia region, we integrated the risk assessment findings described above in a two layer model (table 1). The first layer is based on the exposure assessment of reservoirs, transmission routes, and determinants. The second layer considers the context factors in the region.

The risk-that is, likelihood of occurrence of each event (acquisition, selection, transmission of antibiotic resistance)-was rated using a qualitative approach as:

- Negligible-the event occurs under exceptional circumstances

- Low-the event occurs some of the time

- Moderate-the event occurs regularly

- High-the event occurs in most circumstances.

Based on this approach, we first rated the level of risk for each event arising from the main causes of the emergence and spread of antibiotic resistance (independent of the context). We then estimated the effect of the context factors on the strength of the main causes.

Several studies argue that the emergence of antibiotic resistance in humans is primarily driven by inappropriate and overuse of antibiotics among humans and animals, compared with environmental antibiotic contamination. We therefore considered that antibiotic use leads to a high risk of emergence of antibiotic resistance in both human and animal reservoirs. ${ }^{14} 44$ Human-to-human transmission in the community, which has long been underestimated, could have the same effect on the spread of antibiotic resistance as transmission in healthcare settings, ${ }^{1819}$ and we estimated these risks as moderate. Transmission of resistant bacteria to human populations through foodborne, or waterborne routes combines a high exposure rate to potentially contaminated food or water with a very low probability of transmission and acquisition of resistance in humans. We therefore considered the risk caused by foodborne and waterborne exposures to be low. Direct contact with contaminated animals or environmental elements is rarely reported, but it is possible that a limited number of people are exposed; we thus considered the risk of transmission to be negligible.

Based on our judgment, and on available documentation, a context factor was classified as decreasing or increasing the strength of a cause of the emergence and spread of antibiotic resistance, and thus decreasing or increasing the likelihood of the occurrence of an event or as having a negligible effect (table 1).

We determined the overall risk of each event occurring in the region by combining the effect of the context factors with the risk from the factors causing the emergence, and spread of antibiotic resistance (fig 1).

For example, we estimated that discharge of antibiotics and antibiotic resistant bacteria and genes into the environment was a moderate risk for selection of resistance and that the low level of wastewater management increased the risk, making it high (fig 1).

We chronologically integrated all the events in the chain leading to the transmission of antibiotic resistance in the human population. To calculate the risk from two consecutive and dependent events in the model, we applied a combination matrix (fig 1). ${ }^{45}$ When several independent events contributed to the estimation of the risk, the event with the highest risk was used. For example, the transmission of antibiotic resistance from the environment to humans is dependent on the emergence and selection of resistance in the environment. Using the combination matrix, ${ }^{45}$ we estimated that the emergence and selection of resistance in the environment, which we rated as a high risk in the region, followed by the environment-to-human transmission of resistance, which we rated as a negligible risk in the region, led to a low level risk of acquisition of resistance among humans (fig 1). 


\begin{tabular}{|c|c|c|c|}
\hline Event & $\begin{array}{l}\text { Main cause of } \\
\text { the event }\end{array}$ & $\begin{array}{l}\text { Risk of event } \\
\text { arising from } \\
\text { main cause }\end{array}$ & Factors in South East Asia region affecting main cause \\
\hline $\begin{array}{l}\text { Emergence } \\
\text { and selection } \\
\text { in humans }\end{array}$ & $\begin{array}{l}\text { Use of antibiotics } \\
\text { in humans }\end{array}$ & High & $\begin{array}{l}\text { Level of antibiotic stewardship for human health } \\
\text { Policy: Few of the } 11 \text { countries have an antibiotic } \\
\text { stewardship policy framework, or programmes, and } \\
\text { nine countries have a national regulatory agency for } \\
\text { medicines. }{ }^{2425} \\
\text { System: Poor enforcement of existing policies for } \\
\text { medicines regulation, and poor enforcement of quality } \\
\text { standards for antibiotics. No monitoring of antibiotic } \\
\text { use, and sales. }{ }^{25} \text { Several countries do not have specific } \\
\text { training/education programmes on antibiotic stewardship } \\
\text { for health professionals. Lack of campaigns to raise } \\
\text { awareness. } \\
\text { Individual level: Poor prescribing practices among health } \\
\text { professionals. Low level of compliance with prescriptions } \\
\text { and poor awareness among the general public }{ }^{2427}\end{array}$ \\
\hline
\end{tabular}

Emergence Use of antibiotics High Level of antibiotic stewardship for animal health, and and selection in animals in animals production

Policy: Few countries have a legal framework for antibiotic

\section{Effect of factors on the likelihood of the event occurring}

Increase

Human consumption of antibiotics is growing

in the region, with India being the largest consumer worldwide in $2010 .^{28}$ Antibiotics are available without a prescription in seven countries, ${ }^{25}$ and substandard quality of antibiotics is common. ${ }^{29}$ Inappropriate prescription by doctors, inappropriate antibiotic courses, and selfmedication occur ${ }^{27}$

Risk of the event adjusted for context

High stewardship in animals. Many countries have developed, or are developing, national strategies for containment of antimicrobial resistance targeting animal health. Only four countries ban antibiotics as growth promotors. ${ }^{3031}$ System: Poor enforcement of existing policies. ${ }^{31}$ Individual level: Limited awareness of, and knowledge about, antibiotic resistance, and antibiotic use among veterinarians and farmers. Illegal use of antibiotics as growth promoters is common.

\begin{tabular}{|c|c|c|c|}
\hline $\begin{array}{l}\text { Emergence } \\
\text { and selection } \\
\text { in the } \\
\text { environment }\end{array}$ & $\begin{array}{l}\text { Release of } \\
\text { antibiotic } \\
\text { residues and } \\
\text { antibiotic } \\
\text { resistant } \\
\text { bacteria or } \\
\text { genes into the } \\
\text { environment }\end{array}$ & Moderate & $\begin{array}{l}\text { Level of wastewater management } \\
\text { Policy: Limited regulation on antibiotic release from } \\
\text { pharmaceutical industries, healthcare settings, or } \\
\text { aquaculture. } \\
\text { System: Poor wastewater management and inefficien } \\
\text { treatment technology. }\end{array}$ \\
\hline
\end{tabular}

\section{\begin{tabular}{ll}
\hline Foodborne & Ingestion of \\
transmission & contaminated
\end{tabular}}

to humans food

\section{Low}

$\begin{array}{ll}\text { Waterborne } & \text { Ingestion of } \\ \text { transmission } & \text { contaminated }\end{array}$

to humans water
Low
Level offood safety
Policy: Several countries do not have a specific food safety

policy, although action plans have been developed in all countries. ${ }^{35}$ Only India, Indonesia, Maldives, Nepal, and Thailand have a food safety agency.

System: Poor enforcement of regulations. ${ }^{35}$ Difficulty in implementing policies in small farms or slaughterhouses. Only Indonesia and Thailand have premarketing inspection and standardised food surveillance (Bhutan to some extent), analytical capacities vary. Standards for domestic food differ from those for exported food.

Individual level: Poor awareness of and compliance with existing regulations among food service providers and retailers. Poor awareness of food handling practices in the general population.

Level water safety

System: Insufficient treatment of distributed water for removal of antibiotic resistant bacteria and genes. Low coverage of piped water, especially in rural settings, and lack of infrastructure maintenance. No surveillance for detection of water contamination, and no response measures. Individual level: Low awareness of water treatment and household storage in the general population.

\begin{tabular}{lllll}
\hline $\begin{array}{l}\text { Environment } \\
\text { Soil, water, } \\
\text { air-to-human } \\
\text { direct }\end{array}$ & $\begin{array}{l}\text { Contact with } \\
\text { contaminated } \\
\text { environment }\end{array}$ & Negligible & No available data & Unknown \\
transmission & & & & \\
\hline $\begin{array}{l}\text { Animal-to- } \\
\text { human direct } \\
\text { transmission }\end{array}$ & $\begin{array}{l}\text { Contact with } \\
\text { contaminated } \\
\text { animal }\end{array}$ & Negligible & No available data & Unknown \\
\hline
\end{tabular}
Bangladesh, and Nepal.

\section{Increase}

More intensive livestock production has started, leading to an increase in the use of antimicrobials. An increase in antibiotic use is projected by 2030 (particularly in India, Indonesia, and Myanmar). ${ }^{32}$ Excessive use of antibiotics for growth promotion, prophylaxis, or metaphylaxis (mass administration to prevent infection, or spread of disease).

\section{Increase}

Antibiotics are released into the environment from healthcare settings, aquaculture activities, and pharmaceutical industries ${ }^{33}$. India is among the main antibiotic producers worldwide; Bangladesh, Indonesia, and Thailand also produce antibiotics. Inadequate safe disposal of healthcare waste ( $८ 45 \%$ of healthcare facilities have adequate systems). ${ }^{34}$ Limited amounts (20-30\%) of wastewater are treated in treatment plants (see regional workshop reports at www.ais. unwater. org/ais/course/view.php?id=6), and treatment methods are not effective in eliminating antibiotic residues, or antibiotic resistant bacteria and genes. $^{33}$

\section{Increase}

Meat consumption has increased in countries in the past few years (http://faostat3.fao.org/D. In Thailand, extended spectrum $\beta$-lactamaseproducing Enterobacteriaceae have been isolated in the pork food chain from farms (75\% of pigs were colonised with extended spectrum $\beta$-lactamase producers), slaughterhouses (20\% of pork meat samples tested positive for extended spectrum $\beta$-lactamase producers), and market retailers, but contamination of cooked meat in markets was uncommon. ${ }^{36}$

\section{Increase}

About $35 \%$ of the population of the countries in the region are exposed to drinking water contaminated with faeces, with higher contamination in rural areas and in unimproved water sources. ${ }^{3738}$

Antibiotic resistant genes have been isolated in drinking water in several countries including India,

\section{High}

Moderate

(Continued) 


\begin{tabular}{|c|c|c|c|c|c|}
\hline \multicolumn{6}{|c|}{ Table 1 | (Continued) } \\
\hline Event & $\begin{array}{l}\text { Main cause of } \\
\text { the event }\end{array}$ & $\begin{array}{l}\text { Risk of event } \\
\text { arising from } \\
\text { main cause }\end{array}$ & Factors in South East Asia region affecting main cause & $\begin{array}{l}\text { Effect of factors on the likelihood of the event } \\
\text { occurring }\end{array}$ & $\begin{array}{l}\text { Risk of the event } \\
\text { adjusted for } \\
\text { context }\end{array}$ \\
\hline \multirow[t]{2}{*}{$\begin{array}{l}\text { Human- } \\
\text { to-human } \\
\text { transmission }\end{array}$} & $\begin{array}{l}\text { Transmission } \\
\text { in healthcare } \\
\text { settings }\end{array}$ & Moderate & $\begin{array}{l}\text { Level of infection prevention and control (IPC) } \\
\text { Policy: Nine countries have national IPC programmes. }{ }^{25} \text { Low } \\
\text { level of governmental health expenditure. } \\
\text { System: Weak implementation of IPC programmes in } \\
\text { healthcare settings. No systematic testing and isolation, } \\
\text { few tools for diagnosis and identification of resistance } \\
\text { patterns for appropriate treatment, no centralised registers } \\
\text { of patients, no active healthcare associated infection } \\
\text { surveillance, and poor hygiene and sanitation in healthcare } \\
\text { settings. }{ }^{34} \text { Limited resources, and poor healthcare } \\
\text { infrastructure and equipment, particularly for IPC. } \\
\text { Individual level: Poor awareness among healthcare workers } \\
\text { of IPC practices. }\end{array}$ & $\begin{array}{l}\text { Increase } \\
\text { Limited data available, but the burden of endemic } \\
\text { healthcare associated infections is very high. }{ }^{41}\end{array}$ & High \\
\hline & $\begin{array}{l}\text { Transmission in } \\
\text { the community }\end{array}$ & Moderate & $\begin{array}{l}\text { Measures to control antibiotic resistance transmission } \\
\text { through hygiene, and sanitation in the community } \\
\text { Policy: Lack of national programmes or campaigns on } \\
\text { hygiene, and sanitation. } \\
\text { System: Low regional coverage of piped water on premises, } \\
\text { particularly in rural settings, and lack of infrastructure } \\
\text { maintenance and technical support from institutions to the } \\
\text { community. } \\
\text { Individual level: Poor education on hygiene. }\end{array}$ & $\begin{array}{l}\text { Increase } \\
\text { Access to water and soap in the household can } \\
\text { be limited, and correlated with poverty. Access } \\
\text { to improved sanitation facilities is }<50 \% \text { in } \\
\text { four countries, and } 11 \% \text { of toilet facilities are } \\
\text { shared. Only five countries met the millennium } \\
\text { development goal target for sanitation. }{ }^{37} \text { The } \\
\text { indiscriminate use of antibiotics in the community } \\
\text { might increase the transmission rates of antibiotic } \\
\text { resistant strains. }\end{array}$ & High \\
\hline
\end{tabular}

\section{Discussion}

Given the size of the population, the high burden of bacterial infections, the high rate of antibiotic resistance, and the contribution of context factors identified in this risk assessment, we believe that the overall risk of the emergence and spread of antibiotic resistance among humans in the WHO South East Asia region is among the highest of the WHO regions. The risk of transmission of antibiotic resistance from animal or environmental reservoirs to humans is high in the context of this region and is mediated by the high risks of foodborne and waterborne transmission. We estimated a high risk of transmission of resistance in healthcare settings and in the community, leading to an overall high

\section{Box 3: Knowledge gaps hindering assessment of the risk of emergence or transmission of antibiotic resistance}

- Acquisition and selection in humans

- Rates of horizontal gene transfer from non-pathogenic commensal bacteria

- Effect of dose and duration of antibiotic course on antibiotic resistance

- Reversibility of resistance after withdrawal of antimicrobial

Acquisition and selection in livestock

- Reversibility of antimicrobial resistance after withdrawal of antimicrobial

Acquisition and selection in the environment

- Persistence of antibiotics in soil, sediment, or water

- Persistence of antibiotic resistant bacteria/antibiotic resistant genes in soil, sediment, or water

- Risks from non-environmental bacteria released in environment

- Rates of horizontal gene transfer from non-environmental to environmental bacteria

- Minimum environmental concentration necessary to select resistance for different antibiotic classes

Animal-to-human transmission

- Dose-response and risk factors for persistence of antibiotic resistant bacteria from animal origin in human flora following ingestion

- Routes, risk factors, and rates of transmission of animal bacteria to human flora other than through ingestion

- Risk factors and rates of horizontal gene transfer from animal bacteria to human bacteria in different human flora (intestinal, skin, nasopharyngeal)

- Efficiency for sustained human-to-human transmission of bacteria or genes from animal origin

Environment-to-human transmission

- Dose-response and risk factors for persistence of antibiotic resistant bacteria from aquatic origin in human flora following ingestion

- Routes, risk factors, and rates of transmission of environmental bacteria to human flora other than through ingestion

- Rates of horizontal gene transfer from environmental to human bacteria in the different human flora (intestinal, skin, nasopharyngeal)

- Efficiency of wastewater treatment on elimination of antibiotics, and antibiotic resistant genes

Transmission in healthcare settings

- Routes, risk factors, and rates of human-to-human transmission of resistant bacteria in healthcare settings

- Efficiency of community acquired strains to spread in healthcare settings

Transmission in the community

- Routes, risk factors, and rates of human-to-human transmission of resistant bacteria in the community

- Efficiency of hospital acquired strains to spread in the community 
risk of transmission of antibiotic resistance among humans in the region.

Although the conclusion could have been reached intuitively, our model considered the main biological causes of antibiotic resistance events and factors specific to the WHO South East Asia region and provides an overall picture of the factors affecting antibiotic resistance. Our assessment highlights the limited benefits of isolated interventions in a specific sector and the need for coordinated interventions to reduce the risk of the emergence and spread of antibiotic resistance. The One Health ${ }^{46}$ approach recommends linking human health and animal and environmental health in planning interventions to tackle antibiotic resistance.

This study has some limitations. First, we focused on the pathogens of international concern. The risks of each event cannot be generalised to pathogens not included here. Second, we did not do a systematic review of the literature to quantify risk estimates. The effects of some determinants on the occurrence of specific events are not reported (contribution of antibiotic resistance in the environment to resistance among humans) or are controversial (contribution of antibiotic use in livestock to resistance among humans ${ }^{17}$ ). These knowledge gaps hindered our estimates of risk. In view of these gaps, listed in box 3, we considered a higher level of risk when uncertainty was high.

This qualitative risk assessment framework is in the early stages of development. Each step depends on more than one main biological determinant, and all steps and associated determinants need to be defined to develop a systematic risk model-semi-qualitative or quantitativein the future. With such a model, it might be possible to get accurate estimates of risk and to measure the effectiveness of interventions on defined outcomes.

In conclusion, despite uncertainties, risk assessment models are needed to characterise the level of risk and to identify important interventions to reduce this risk and to reduce knowledge and system gaps while analysing processes and outcomes. We believe such a model with defined parameters will be of interest at the country level to identify system weaknesses, and assess the effect of measures to control antibiotic resistance.

Contributors and sources: FC and SV wrote the article, LO and MT reviewed the article, SV designed the study, LO, FC, and SV designed the framework model, and FC, LO, and MT searched the literature. All authors reviewed, and approved the final manuscript. $\mathrm{SV}$ is the guarantor. The opinions expressed in this paper are those of the authors, and do not necessarily represent those of the institutions with which the authors are affiliated.

Competing interests: We have read and understood BMJ policy on declaration of interests, and declare funding from the UK Department of Health Fleming Fund.
Provenance and peer review: Commissioned; externally peer reviewed.

This article is one of a series commissioned by The $B M$ J based on an idea from WHO SEARO The BMJ retained full editorial control over external peer review, editing, and publication. Open access fees are funded by the WHO SEARO.

Fanny Chereau, technical officer, health emergency information and risk assessment ${ }^{1}$

Lulla Opatowski, consultant ${ }^{12}$

Mathieu Tourdjman, consultant ${ }^{3}$

Sirenda Vong, programme area manager, health emergency information and risk assessment ${ }^{1}$ ${ }^{1}$ World Health Organization Regional Office for South East Asia, New Delhi, India

${ }^{2}$ Institut Pasteur, Paris, France

${ }^{3}$ Saint-Louis University Hospital, Paris, France Correspondence to: SVong

vongs@who.int

\section{World Health Organization. Global} action plan on antimicrobial resistance. 2015. http://apps.who.int/iris/ bitstream/10665/193736/1/9789241509763 eng.pdf?ua $=1$

2 World Health Organization. Rapid risk assessment of acute public health events. 2012 http://apps.who. int/iris/bitstream/10665/70810/1/WHO_HSE_ GAR_ARO_2012.1_eng.pdf

3 World Health Organization. Antimicrobial resistance: global report on surveillance. 2014. http://apps.who.int/iris/ bitstream/10665/112642/1/9789241564748 eng.pdf?ua $=1$

4 ECDC. EMEA. The bacterial challenge: time to react. 2009. https://ecdc.europa.eu/sites/portal/files/ media/en/publications/Publications/0909_TER The_Bacterial_Challenge_Time_to_React.pdf Woerther P-L, Burdet C, Chachaty E, Andremont A. Trends in human fecal carriage of extendedspectrum $\beta$-lactamases in the community: toward the globalization of CTX-M. Clin Microbiol Rev 2013;26:744-58. doi:10.1128/CMR. 00023-13

6 Chen C-J, Huang Y-C. New epidemiology of Staphylococcus aureus infection in Asia. Clin Microbiol Infect 2014;20:605-23. doi:10.1111/1469-0691.12705 Karanika S, Karantanos T, Arvanitis M, Grigoras C, Mylonakis E. Fecal colonization with extended-spectrum beta-lactamase-producing Enterobacteriaceae and risk factors among healthy individuals: a systematic review and meta-analysis. Clin Infect Dis 2016;63:310-8. doi:10.1093/cid/ ciw283

8 Food and Agriculture Organization. Drivers, dynamics and epidemiology of antimicrobial resistance in animal production. 2016. https://www.mrc.ac.uk/ documents/pdf/antimicrobial-resistance-timelinereport/

9 Bell BG, Schellevis F, Stobberingh E, Goossens H, Pringle M. A systematic review and meta-analysis of the effects of antibiotic consumption on antibiotic resistance. BMC Infect Dis 2014;14:13. doi:10.1186/1471-2334-14-13

10 Landers TF, Cohen B, Wittum TE, Larson EL. A review of antibiotic use in food animals: perspective, policy, and potential. Public Health Rep 2012;127:4-22. doi:10.1177/003335491212700103

11 Lipsitch M. Samore MH. Antimicrobial use and antimicrobial resistance: a population perspective. Emerg Infect Dis 2002;8:347-54. doi:10.3201/ eid0804.010312

12 Wellington EMH, Boxall AB, Cross P. The role of the natural environment in the emergence of antibiotic resistance in gram-negative bacteria. Lancet Infect Dis 2013;13:155-65. doi:10.1016/S14733099(12)70317-1

13 Taylor NGH, Verner-Jeffreys DW, Baker-Austin C. Aquatic systems: maintaining, mixing and mobilising antimicrobial resistance?Trends Ecol Evol 2011;26:278-84. doi:10.1016/j. tree.2011.03.004
14 Smith DL, Dushoff J, Morris JG. Agricultural antibiotics and human health. PLoS Med 2005;2:e232. doi:10.1371/journal.pmed.0020232

15 Founou LL, Founou RC, Essack SY. Antibiotic resistance in the food chain: a developing country-perspective. Front Microbiol 2016;7:1881 doi:10.3389/fmicb.2016.01881

16 Aarestrup FM. The livestock reservoir for antimicrobial resistance: a personal view on changing patterns of risks, effects of interventions and the way forward. Philos Trans R Soc Lond B Biol Sci 2015;370:20140085. doi:10.1098/rstb.2014.0085

17 Chang Q, Wang W, Regev-Yochay G, Lipsitch M, Hanage WP. Antibiotics in agriculture and the risk to human health: how worried should we be?Evol Appl 2015;8:240-7. doi:10.1111/eva.12185

18 Knox J, Uhlemann A-C, Lowy FD. Staphylococcus aureus infections: transmission within households and the community. Trends Microbiol 2015;23: 437-44. doi:10.1016/j.tim.2015.03.007

19 Hilty M, Betsch BY, Bögli-Stuber K. Transmission dynamics of extended-spectrum $\beta$-lactamaseproducing Enterobacteriaceae in the tertiary care hospital and the household setting. Clin Infect Dis 2012;55:967-75. doi:10.1093/cid/cis581

20 Lawes T, Lopez-Lozano J-M, Nebot CA. Effects of national antibiotic stewardship and infection control strategies on hospital-associated and communityassociated meticillin-resistant Staphylococcus aureus infections across a region of Scotland: a non-linear time-series study. Lancet Infect Dis 2015;15: 1438-49. doi:10.1016/S1473-3099(15)00315-1

21 Tacconelli E, Cataldo MA, Dancer SJEuropean Society of Clinical Microbiology. ESCMID guidelines for the management of the infection control measures to reduce transmission of multidrug-resistant Gram-negative bacteria in hospitalized patients Clin Microbiol Infect 2014;20(Suppl 1):1-55. doi:10.1111/1469-0691.12427

22 McCarthy AJ, Loeffler A, Witney AA, Gould KA, Lloyd DH, Lindsay JA. Extensive horizontal gene transfer during Staphylococcus aureus cocolonization in vivo. Genome Biol Evol 2014;6: 2697-708. doi:10.1093/gbe/evu214

23 Hetem DJ, Bootsma MCJ, Troelstra A, Bonten MJM. Transmissibility of livestock-associated methicillinresistant Staphylococcus aureus. Emerg Infect Dis 2013;19:1797-802. doi:10.3201/ eid1911.121085

24 World Health Organization Regional Office for South-East Asia. Antimicrobial resistance. Report of a regional meeting Jaipur, India, 10-13 November 2014. 2015 http://www.searo.who.int/entity/ antimicrobial_resistance/sea_hlm_423.pdf?ua=1 (accessed March 20, 2017).

25 World Health Organization. Worldwide country situation analysis: response to antimicrobial resistance. 2015. http://apps.who.int/iris/ bitstream/10665/163468/1/9789241564946_ eng.pdf?ua $=1 \& u a=1$

26 Godhino N, Bezbaruah S, Neyyar S. Antimicrobial resistance communication activities in South East Asia. BMJ 2017;358:j2742

27 Holloway KA, Kotwani A, Batmanabane G, Puri M, Tisocki K. Antibiotic use in South East Asia and policies to promote appropriate use: reports from country situational analyses. BMJ 2017;358:j2440.

28 Gelband H, Miller-Petrie M, Pant S, et al. The state of the world's antibiotics, 2015. The Center for Disease Dynamics, Economics \& Policy, 2015 http://www. cddep.org/publications/state worlds antibiotics_20 15\#sthash.40to7/Rd.aUiQVDOc.dpbs.

29 Kelesidis T, Falagas ME. Substandard/ counterfeit antimicrobial drugs. Clin Microbiol Rev 2015;28:443-64. doi:10.1128/CMR.00072-14

30 Chuanchuen R, Pariyotorn N, Siriwattanachai K, et al. Review of the literature on antimicrobial resistance in zoonotic bacteria from livestock in East, South and Southeast Asia. Food and Agriculture Organization Regional Office for Asia and the Pacific. 2014 http:// cdn.aphca.org/dmdocuments/REP_AMR_141022_c. pdf.

31 Goutard FL, Bourdier M, Calba C. Antimicrobial policy interventions in food animal production in South East Asia. BMJ 2017:358:j3544 
32 Van Boeckel TP, Brower C, Gilbert M. Global trends in antimicrobial use in food animals. Proc Natl Acad Sci U S A 2015;112:5649-54. doi:10.1073/ pnas.1503141112

33 Lundborg CS, Tamhankar AJ. Antibiotic residues in the environment of South East Asia. BMJ 2017;358:j2440.

34 World Health Organization, Unicef. Water. sanitation and hygiene in health care facilities. Status in low- and middle-income countries and way forward. 2015. http://apps.who.int/iris/ bitstream/10665/154588/1/9789241508476_ eng.pdf

35 World Health Organization Regional Office for SouthEast Asia. Regional food safety strategy. 2014. http:// www.searo.who.int/entity/foodsafety/regional-foodstrategy.pdf?ua=1

36 Boonyasiri A, Tangkoskul T, Seenama C, Saiyarin J, Tiengrim S, Thamlikitkul V. Prevalence of antibiotic resistant bacteria in healthy adults, foods, food animals, and the environment in selected areas in Thailand. Pathog Glob Health 2014;108:235-45. doi $: 10.1179 / 2047773214$ Y.0000000148
37 World Health Organization. Unicef. A snapshot of drinking water and sanitation in WHO South-East Asia Region. 2014. http://www.searo.who.int/ entity/water_sanitation/data/watsancoverage. pdf?ua=1

38 Bain R, Cronk R, Hossain R. Global assessment of exposure to faecal contamination through drinking water based on a systematic review. Trop Med Int Health 2014;19:917-27. doi:10.1111/tmi.12334

39 Majumder MAA. Economics of healthcare financing in WHO South East Asia Region. South East Asia J Public Health 2013;2:3-4doi:10.3329/seajph. v2i2.15936.

40 World Health Organization Regional Office for SouthEast Asia. Regional strategy for patient safety in the WHO South-East Asia Region. 2015. http://apps. who.int/iris/bitstream/10665/205839/1/B5215. pdf.

41 Ling ML, Apisarnthanarak A, Madriaga G. The burden of healthcare-associated infections in southeast Asia: A systematic literature review and meta-analysis. Clin Infect Dis 2015;60:1690-9. doi:10.1093/cid/civ095
42 Holloway KA, Kotwani A, Batmanabane G. Antibiotic use in South East Asia and policies to promote appropriate use: reports from country situational analyses. BMJ 2017;358:j2991. doi:10.1136/bmj. i2291.

43 Kakkar M, Walia K, Vong S. Antibiotic resistance and its containment in India. BMJ 2017;358:j2687. doi:10.1136/bmj.j2687.

44 Holmes AH, Moore LSP, Sundsfiord A. Understanding the mechanisms and drivers of antimicrobial resistance. Lancet 2016;387:176-87. doi:10.1016/ S0140-6736(15)00473-0

45 Wieland B, Dhollander S, Salman M, Koenen F. Qualitative risk assessment in a data-scarce environment: a model to assess the impact of control measures on spread of African Swine Fever. Prev Vet Med 2011;99:4-14. doi:10.1016/j. prevetmed.2011.01.001.

46 Centers for Disease Control and Prevention. One Health. https://www.cdc.gov/onehealth/

Cite this as: BMJ 2017;358:j3393

http://dx.doi.org/10.1136/bmj.j3393

This an open access article distributed under the terms of the Creative Commons Attribution-non-commercial IGO License (https:// creativecommons.org/licenses/by-nc/3.0/igo/), which permits use, distribution, and reproduction for non-commercial purposes in any medium, provided the original work is properly cited. In any reproduction of this article there should not be any suggestion that WHO or this article endorse any specific organisation or products. The use of the WHO logo is not permitted. This notice should be preserved along with the article's original URL. 